\title{
Factors associated with disease progression and viral replication in patients with chronic hepatitis B virus infection
}

\author{
JING JIA $^{1 *}$, YONGHONG LI ${ }^{*}$, CHAOJUN WEI ${ }^{1}$, RUI GUO ${ }^{1}$, HUI XU ${ }^{1}$, YANJUAN JIA ${ }^{1}$, YU WU $^{1}$, \\ YUANTING LI ${ }^{1}$, ZHENHONG WEI ${ }^{2}$, XIAOMING $\mathrm{QI}^{1}$, ZHENHAO LI ${ }^{1}$ and XIAOLING GAO ${ }^{1}$ \\ ${ }^{1}$ Institute of Clinical Research and Translational Medicine, Gansu Provincial Hospital; \\ ${ }^{2}$ Department of Blood Transfusion, Gansu Provincial Hospital, Lanzhou, Gansu 730000, P.R. China
}

Received September 25, 2018; Accepted March 7, 2019

DOI: $10.3892 /$ etm.2019.7482

\begin{abstract}
Hepatitis B virus (HBV) infection remains a severe clinical concern in China. Of note, the progression of HBV infection varies between different populations. To identify the factors that influence the disease progression and prognosis, a total of 478 chronic HBV-infected patients were enrolled, and liver function parameters, HBV DNA levels and hepatic fibrosis indices were analyzed. First, the results demonstrated a significant difference in hepatitis B e antigen (HBeAg) expression between male and female patients $\left(\chi^{2}=4.061, \mathrm{P}=0.044\right)$. Furthermore, when comparing either HBeAg-negative or -positive male and female patients, males exhibited a greater variation in HBV DNA levels. Although significant differences between male and female patients in certain abnormal ratios of liver function parameters were identified, a trend in the differences was observed in the $\mathrm{HBeAg}$-negative and -positive groups. When considering age, the results of the present study confirmed that HBV DNA levels decreased with advanced age, and the values of the majority of biomarkers exhibited an evident decreasing trend
\end{abstract}

Correspondence to: Professor Xiaoling Gao, Institute of Clinical Research and Translational Medicine, Gansu Provincial Hospital, 204 Donggang West Road, Lanzhou, Gansu 730000, P.R. China

E-mail: gaox1008@hotmail.com

${ }^{*}$ Contributed equally

Abbreviations: HBV, hepatitis B virus; HCC, hepatocellular carcinoma; $\mathrm{HBeAg}$, hepatitis $\mathrm{B}$ e antigen; HBsAg, hepatitis B surface antigen; TP, total protein; ALB, albumin; GLB, globulin; A/G, albumin/globulin; TBIL, total bilirubin; DBIL, direct bilirubin; IBIL, indirect bilirubin; ALT, alanine aminotransferase; AST, aspartate aminotransferase; GGT, $\gamma$-glutamyl transpeptidase; ALP, alkaline phosphatase; TBA, total biliary acid; HA, hyaluronic acid; LN, laminin; PCIIINP, procollagen III N-terminal peptide; IV-C, serum IV collagen

Key words: hepatitis B, hepatitis B e antigen expression, gender, age, precision medicine with increasing age. In addition, it was demonstrated that all $\mathrm{HBeAg}$ seropositive patients had higher levels of hepatic fibrosis indexes and higher abnormal ratios of hepatic fibrosis values in their serum when compared with those of $\mathrm{HBeAg}$ seronegative patients, particularly with regard to serum IV collagen. The present results revealed that HBV DNA replication was closely associated with liver function; however, it was notable that in $\mathrm{HBeAg-negative} \mathrm{patients,} \mathrm{the} \mathrm{association}$ between HBV DNA levels and liver function was particularly significant among subjects aged $<61$. Furthermore, this result was not observed in $\mathrm{HBeAg}$-positive patients. In conclusion, the present study indicated the importance of host factors (including sex and age) and viral factors (including $\mathrm{HBeAg}$ expression pattern and HBV DNA levels) in the progression of chronic HBV infection, and its influence regarding prognosis and treatment. The present results provide a foundation for clinical management strategies for chronic HBV infection, particularly in individual schemes.

\section{Introduction}

Hepatitis B virus (HBV) infection remains a severe clinical issue worldwide, particularly in China (1), despite the number of prophylactic vaccines and effective anti-viral medicines that are available to treat HBV. The social and economic burden remains serious, but no concerted efforts have been made by communities to increase awareness and improve access to care (2-4). In China, the rates of HBV infection vary greatly across different regions and populations (5), and the incurred liver damage also varies in each individual due to physical differences.

HBV leads to a variety of clinical symptoms, ranging from the affected individual being an asymptomatic carrier to hepatocellular carcinoma (HCC). Progression of HBV infection is as a consequence of combined factors, including the host immune response, as well as age, sex, viral genotypes and environmental factors (6-8). According to a statistical survey, male and female patients present with different responses to HBV infection and males have a greater risk of developing HCC than females (9). This may be due to the opposite effects of the sex hormones androgen and estrogen (8). In addition, age appears to serve an important role in predicting significant fibrosis progression in patients and in chronic hepatitis B 
treatment $(10,11)$. It was therefore hypothesized that the host's characteristics may be critical regarding the progression of HBV infection, which should be taken into consideration by physicians when selecting the correct treatment and prevention strategy.

The progression of HBV infection may be detected by histological observation of the accumulation of fibrosis and physiologically by liver function injury (12). Certain studies have demonstrated that liver function markers, including albumin (ALB), bilirubin, alanine aminotransferase (ALT), aspartate aminotransferase (AST) and AST/ALT exhibited a marked variation among different patients infected with HBV (13). In addition, HBV DNA serves a central role in maintaining persistent infection (14). A number of previous studies have revealed that the HBV DNA levels are associated with the extent of liver damage and liver fibrosis severity $(15,16)$. It may be used as an independent factor to predict the response to anti-viral treatment (17-19). In addition, HBV DNA is a virological marker that reflects HBV replication levels.

Hepatic fibrosis is the pathological change caused by chronic liver damage. It is a necessary developmental stage from chronic liver disease to liver cirrhosis (20). The early stage of hepatic fibrosis is reversible, and therefore the prevention and control of early liver fibrosis are of great significance. Although numerous anti-viral drugs have been introduced to control HBV replication, the subsequent emergence of HBV drug resistance has made it harder to control $\mathrm{HBV}$ infection and prevent liver fibrosis (21). The exploration of biomarkers of early liver fibrosis remains a feasible strategy to identify and possibly prevent disease progression in chronic $\mathrm{HBV}$ infection in the future.

Hepatitis B e antigen ( $\mathrm{HBeAg}$ ) is a critical indicator to determine the severity of the disease and it is associated with the activity of viral replication and infectivity (22). In addition, $\mathrm{HBeAg}$ analysis is useful for predicting seroconversion and disease progression (23). However, how HBeAg expression influences HBV DNA levels, liver function and hepatic fibrosis remains elusive.

The present study investigated the potential role of sex and age in HBV infection depending on different HBeAg statuses, providing a further reference for clinical treatment strategies in different patients. A total of 478 patients were enrolled and were then divided into 2 groups according to their $\mathrm{HBeAg}$ serum levels. The serum biomarkers of liver function, HBV DNA levels and hepatic fibrosis indices were then analyzed and compared between different subgroups. In addition, the roles of the HBeAg expression status in $\mathrm{HBV}$ infection progression were explored. The correlation between $\mathrm{HBeAg}$ expression status and either HBV DNA levels, liver function biomarkers or fibrosis index values were also determined. The results demonstrated that sex, age and $\mathrm{HBeAg}$ expression status markedly influenced the progression of the HBV infection as well as the viral load represented by HBV DNA.

\section{Materials and methods}

Study population. A total of 478 patients admitted to Gansu Provincial Hospital (Gansu, China) between March 2015 and July 2016 were enrolled in the present study. Participants were permanent residents of Gansu province, recruited from rural and urban areas. The diagnostic criteria used were based on the Guidelines for the Prevention and Treatment of Chronic Hepatitis B from 2015, which was issued by Chinese Society of Hepatology of Chinese Medical Association and the Society of Infectious Diseases from the Chinese Medical Association (24). The present study was approved by the Ethics Review Committee of Gansu Provincial Hospital (Lanzhou, China) and all patients provided their written informed and consent.

All of the patients exhibited impaired liver function or extremely high viral load and had been serum hepatitis B surface antigen (HBsAg)-positive for $>6$ months without hepatitis $\mathrm{C}$ virus or human immunodeficiency virus coinfection. Patients exhibited no evidence of alcohol abuse at the time of diagnosis and initiation of the study. The baseline values of each patient was collected and analyzed. There were no differences between age/sex either for the duration of treatment or that of infection. However, there may be some errors in data due to patients incorrectly recalling the time of infection. Blood samples were obtained from all of the patients following treatment, and the majority of the enrolled patients had received entecavir (ETV) and/or tenofovir (TDF) therapy, the first-line drugs according to the abovementioned guidelines. The number of patients treated with different drugs to ETV and TDF was relatively small. Demographic characteristics, including gender and age, were recorded during interviews.

Virological and serological marker tests. Quantitation of HBV DNA and 13 liver function biomarkers, as well as determination of the HBsAg and $\mathrm{HBeAg}$ status, were performed in all of the patients. The detection of HBV DNA was performed by using real-time fluorescent-quantitative (q)PCR on a Roche Light Cycler 480II (Roche Diagnostics). The HBV DNA PCR-Fluorescence Quantitative Diagnostic kit (Shenzhen Qiagen Bio-Engineering, Shenzhen, China) was used for HBV DNA extraction. The reaction volume was $50 \mu 1$. The thermocycling conditions were as follows: $37^{\circ} \mathrm{C}$ for $5 \mathrm{~min}$, then $95^{\circ} \mathrm{C}$ for $5 \mathrm{~min}$, followed by 45 cycles of $95^{\circ} \mathrm{C}$ for $15 \mathrm{sec}$ and $60^{\circ} \mathrm{C}$ for $40 \mathrm{sec}$, and then a final extension at $72^{\circ} \mathrm{C}$ for $5 \mathrm{~min}$.

Liver function biomarkers, including total protein (TP), ALB, globulin (GLB), total bilirubin (TBIL), direct bilirubin (DBIL), indirect bilirubin (IBIL), ALT, AST, $\gamma$-glutamyl transpeptidase (GGT), alkaline phosphatase (ALP) and total biliary acid (TBA) were measured using an Olympus AU5400 auto biochemical analyzer (Olympus Corp.) using the manufacturer's reagents. The ALB vs. GLB ratio $(\mathrm{A} / \mathrm{G})$ and AST/ALT were calculated according to the values of ALB, GLB, ALT and AST. The hepatic fibrosis indexes were quantified using chemiluminescence (AutoLumo A2000; AutoBio Diagnostics Co., Ltd.). The experimental methods and reference range of each parameter are summarized in Table I. HBsAg and HBeAg levels were detected by I2000 immunoassay (Abbott Pharmaceutical Co., Ltd.) in accordance with the manufacturer's protocols. All serological markers were tested by the Clinical Laboratory Center of Gansu Provincial Hospital (Lanzhou, China).

Statistical analysis. SPSS statistical software (version 19.0; IBM Corp.) was used for statistical analysis. Descriptive statistics, including the mean, standard deviation, frequency and rate were used. All values are expressed as the mean \pm standard 
Table I. Summary of test methods and reference ranges for each parameter.

\begin{tabular}{llc}
\hline Parameter & \multicolumn{1}{c}{ Method } & Reference range \\
\hline TP $(\mathrm{g} / \mathrm{l})$ & Biuret method & $65.0-85.0$ \\
$\mathrm{ALB}(\mathrm{g} / \mathrm{l})$ & Bromocresol green method & $40.0-55.0$ \\
TBIL $(\mu \mathrm{mol} / \mathrm{l})$ & Diazonium salt method & $5.1-29.6$ \\
DBIL $(\mu \mathrm{mol} / \mathrm{l})$ & Diazonium salt method & $0.0-6.8$ \\
ALT $(\mathrm{U} / \mathrm{l})$ & Alanine substrate method & $9.0-50.0$ \\
AST $(\mathrm{U} / \mathrm{l})$ & Aspartic acid substrate method & $15.0-40.0$ \\
$\mathrm{GGT}(\mathrm{U} / \mathrm{l})$ & GCANA substrate method & $10.0-60.0$ \\
ALP $(\mathrm{U} / \mathrm{l})$ & NPP substrate-AMP buffer method & $45.0-125.0$ \\
TBA $(\mu \mathrm{mol} / \mathrm{l})$ & Enzyme colorimetry & $0-15.0$ \\
HA $(\mathrm{ng} / \mathrm{ml})$ & Magnetic particle chemiluminescence & $<120.0$ \\
LN $(\mathrm{ng} / \mathrm{ml})$ & Magnetic particle chemiluminescence & $<130.0$ \\
PCIIINP $(\mathrm{ng} / \mathrm{ml})$ & Magnetic particle chemiluminescence & $<15.0$ \\
IV-C $(\mathrm{ng} / \mathrm{ml})$ & Magnetic particle chemiluminescence & $<95.0$ \\
\hline
\end{tabular}

TP, total protein; ALB, albumin; TBIL, total bilirubin; DBIL, direct bilirubin; ALT, alanine aminotransferase; AST, aspartate aminotransferase; GGT, $\gamma$-glutamyl transpeptidase; ALP, alkaline phosphatase; TBA, total biliary acid; HA, hyaluronic acid; LN, laminin; PCIIINP, procollagen III N-terminal peptide; IV-C, serum IV collagen.

deviation. Furthermore, the Chi-square test and independent-samples Student's t-test were used to compare parameters among different groups. Spearman correlation coefficient analysis was employed to explore the correlation between different DNA levels and the patients' liver function. One-way analysis of variance and an independent-samples Student's t-test were used to analyze the differences between two groups following correction via the Bonferroni method in various age groups. The $95 \%$ confidence intervals were determined for all results. $\mathrm{P}<0.05$ was considered to indicate a statistically significant difference.

\section{Results}

Population characteristics. A total of $478 \mathrm{HBsAg}$-positive patients were selected for the present study. The baseline demographic data of the cohort were obtained through patient interviews, written records and the hospital's electronic database. Laboratory data were obtained from the database of Gansu Province Hospital (Lanzhou, China). As summarized in Table II, of the 478 patients aged from 4 to 90 years (mean age, $41.01 \pm 14.31$ years), 254 were male $(53.1 \%)$ and 224 were female (46.9\%). Furthermore, 254 patients $(53.1 \%)$ were $\mathrm{HBeAg}$-negative and 224 (46.9\%) were $\mathrm{HBeAg}$-positive. All patients donated blood samples and had undergone HBV DNA detection. The mean peripheral HBV viral load in $\log _{10}$ was $4.45 \pm 1.87 \mathrm{IU} / \mathrm{ml}$. HBV DNA levels were undetectable in $32.6 \%(156 / 478)$ of patients.

The laboratory parameters of all patients and the proportion of patients beyond the normal range were calculated and are presented in Table III. The majority of patients in the present study exhibited reduced liver function and the rates of hepatic fibrosis abnormalities were also lower. Only procollagen III N-terminal peptide (PCIIINP) was observed to be increased in $62.4 \%$ of patients infected with HBV.
Table II. Characteristics of the patients with hepatitis B virus $(n=478)$.

\begin{tabular}{lc}
\hline Characteristic & Value \\
\hline Sex & \\
Male & $254(53.1)$ \\
Female & $224(46.9)$ \\
Age (years) & $41.01 \pm 14.31(4-90)$ \\
HBeAg & \\
Negative & $254(53.1)$ \\
Positive & $224(46.9)$ \\
HBV-DNA & \\
Negative & $156(32.6)$ \\
Positive & $322(67.4)$ \\
$\left(\log _{10} \mathrm{IU} / \mathrm{ml}\right)$ & $4.45 \pm 1.87(2.77-8.00)$ \\
\hline
\end{tabular}

Values are expressed as either the mean \pm standard deviation (min-max) or $\mathrm{n}(\%)$. HBeAg, hepatitis B e antigen; HBV, hepatitis $\mathrm{B}$ virus.

Clinical measurements based on the expression of HBeAg. In general, $\mathrm{HBeAg}$ is a critical serological marker used to assess the infectivity and prognosis of a patient (23). To investigate whether qualitative $\mathrm{HBeAg}$ may serve as a marker to indicate the degree of liver injury in HBV carriers, all of the 478 patients were divided into 2 groups according to their $\mathrm{HBeAg}$ status (Table III), and the association between $\mathrm{HBeAg}$ and HBV replication levels, as well as parameters of liver function, were analyzed.

First, the population demographics were analyzed based on gender and age. Of note, it was indicated that a larger proportion of male patients were $\mathrm{HBeAg}$-positive when 
Table III. Comparison of hepatic fibrosis and liver function parameters between HBeAg-positive and -negative groups.

\begin{tabular}{|c|c|c|c|c|c|}
\hline Parameter & Value & $\begin{array}{l}\text { Ratio of patients } \\
\text { beyond the } \\
\text { normal range (\%) }\end{array}$ & $\begin{array}{l}\text { HBeAg-negative } \\
\quad(n=254)\end{array}$ & $\begin{array}{l}\text { HBeAg-positive } \\
\quad(n=224)\end{array}$ & P-value \\
\hline $\operatorname{Sex}^{\mathrm{a}}$ & & & & & 0.044 \\
\hline Male $(n=254)$ & N/A & N/A & $124(49)$ & $130(51)$ & \\
\hline Female $(n=224)$ & N/A & N/A & $130(58)$ & $94(42)$ & \\
\hline Age (years) ${ }^{b}$ & N/A & N/A & $44.37 \pm 14.78$ & $37.21 \pm 12.75$ & $<0.001$ \\
\hline HBV DNA ${ }^{a}$ & & & & & $<0.001$ \\
\hline Negative & N/A & N/A & $125(49.2)$ & $31(13.8)$ & \\
\hline Positive & N/A & N/A & $129(50.8)$ & $193(86.2)$ & \\
\hline$\left(\log _{10} \mathrm{IU} / \mathrm{ml}\right)$ & N/A & N/A & $3.50 \pm 1.22$ & $5.53 \pm 1.90$ & $<0.001$ \\
\hline \multicolumn{6}{|c|}{ Liver function parameters ${ }^{\mathrm{b}}$} \\
\hline $\mathrm{TP}(\mathrm{g} / \mathrm{l})$ & $69.07 \pm 7.14(37-86)$ & 22.6 & $68.26 \pm 7.77$ & $70.00 \pm 6.24$ & 0.007 \\
\hline $\operatorname{ALB}(g / l)$ & $42.40 \pm 6.54(4.0-52.8)$ & 29.9 & $42.46 \pm 6.30$ & $42.34 \pm 6.82$ & 0.837 \\
\hline GLB $(g / l)$ & $26.58 \pm 5.01(15.0-49.5)$ & 8.8 & $24.33 \pm 3.37$ & $28.19 \pm 4.89$ & $<0.001$ \\
\hline $\mathrm{A} / \mathrm{G}$ & $1.66 \pm 0.41(0.57-3.46)$ & 16.9 & $1.79 \pm 0.36$ & $1.56 \pm 0.38$ & $<0.001$ \\
\hline $\operatorname{TBIL}(\mu \mathrm{mol} / \mathrm{l})$ & $25.60 \pm 44.41(4.7-627.2)$ & 17.4 & $24.52 \pm 45.15$ & $26.83 \pm 43.62$ & 0.573 \\
\hline DBIL $(\mu \mathrm{mol} / \mathrm{l})$ & $8.64 \pm 25.54(0.3-385.2)$ & 23.8 & $8.25 \pm 27.06$ & $9.09 \pm 23.74$ & 0.722 \\
\hline IBIL $(\mu \mathrm{mol} / \mathrm{l})$ & $16.96 \pm 20.69(2.3-242.0)$ & 13.6 & $16.27 \pm 18.83$ & $17.74 \pm 22.63$ & 0.440 \\
\hline $\operatorname{ALT}(\mathrm{U} / \mathrm{l})$ & $83.93 \pm 233.27(7-3404)$ & 34.5 & $65.73 \pm 189.82$ & $104.58 \pm 273.35$ & 0.070 \\
\hline $\operatorname{AST}(\mathrm{U} / \mathrm{l})$ & $76.74 \pm 225.06(8-2360)$ & 37.7 & $55.85 \pm 175.61$ & $102.55 \pm 272.62$ & 0.081 \\
\hline AST/ALT & $1.05 \pm 1.01(0.18-15.1)$ & NA & $1.04 \pm 0.68$ & $1.06 \pm 1.30$ & 0.801 \\
\hline GGT (U/l) & $51.49 \pm 73.18(6.5-718.3)$ & 27.8 & $41.92 \pm 62.20$ & $63.45 \pm 83.65$ & 0.012 \\
\hline $\operatorname{ALP}(\mathrm{U} / \mathrm{l})$ & $104.38 \pm 65.23(3-755)$ & 21.4 & $97.28 \pm 43.73$ & $113.21 \pm 84.05$ & 0.044 \\
\hline $\mathrm{TBA}(\mu \mathrm{mol} / \mathrm{l})$ & $15.08 \pm 38.30(0.1-331)$ & 18.8 & $9.71 \pm 21.41$ & $21.74 \pm 51.48$ & 0.011 \\
\hline \multicolumn{6}{|l|}{ Hepatic fibrosis ${ }^{\mathrm{b}}$} \\
\hline $\mathrm{HA}(\mathrm{ng} / \mathrm{ml})$ & $178.50 \pm 171.47(15-725)$ & 47.1 & $159.83 \pm 143.02$ & $220.32 \pm 220.23$ & 0.216 \\
\hline $\mathrm{LN}(\mathrm{ng} / \mathrm{ml})$ & $106.25 \pm 69.11(19-520)$ & 23.5 & $101.64 \pm 51.77$ & $115.64 \pm 95.72$ & 0.474 \\
\hline PCIIINP (ng/ml) & $58.16 \pm 60.04(5-295)$ & 62.4 & $57.69 \pm 52.44$ & $59.11 \pm 74.25$ & 0.919 \\
\hline IV-C (ng/ml) & $87.68 \pm 67.46(16-362)$ & 27.1 & $75.51 \pm 52.62$ & $112.46 \pm 86.40$ & 0.044 \\
\hline
\end{tabular}

Values are expressed as either the mean \pm standard deviation (min-max) or mean \pm standard deviation; the limit from min to max was calculated

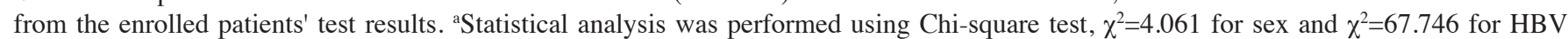
DNA; 'Statistical analysis was performed using independent-samples Student's t-test. TP, total protein; ALB, albumin; GLB, globulin; A/G, albumin/globulin; TBIL, total bilirubin; DBIL, direct bilirubin; IBIL, indirect bilirubin; ALT, alanine aminotransferase; AST, aspartate aminotransferase; GGT, $\gamma$-glutamyl transpeptidase; ALP, alkaline phosphatase; TBA, total biliary acid; HA, hyaluronic acid; LN, laminin; PCIIINP, procollagen III N-terminal peptide; IV-C, serum IV collagen.

compared with female patients, while more female than male patients were HBeAg-negative $\left(\chi^{2}=4.061, \mathrm{P}=0.044\right.$; Table III). The average age of HBeAg-positive patients was $37.21 \pm 12.75$ years, which was significantly lower than that in patients with undetectable $\mathrm{HBeAg}$ in their peripheral blood $(\mathrm{P}<0.05$; Table III). In the HBeAg-positive group, 193 patients (86.2\%) were HBV DNA-positive, with $\log _{10}$ values ranging from 2.97 to $8.00 \mathrm{IU} / \mathrm{ml}$ (the mean $\log _{10}$ of the viral load was $5.53 \pm 1.90 \mathrm{IU} / \mathrm{ml})$. The cutoff for HBV DNA replication was defined as $500 \mathrm{IU} / \mathrm{ml}$ in all patients. Only $50.8 \%$ of patients had viral replication in the $\mathrm{HBeAg-negative} \mathrm{group,} \mathrm{and} \mathrm{the}$ viral load (mean viral load, $3.50 \pm 1.22 \log _{10} \mathrm{IU} / \mathrm{ml}$ ) was significantly lower than that in the HBeAg-positive group $(\mathrm{P}<0.05)$.

Regardless of whether any statistically significant differences were observed, all of the patients with seropositive
HBeAg had increased liver functional proteins and higher levels of hepatic fibrosis indexes in their serum than those in the seronegative $\mathrm{HBeAg}$ group, except for ALB and A/G. In particular, the levels of TP, GLB, GGT, ALP and TBA were significantly higher in the HBeAg-positive group compared with those in the HBeAg-negative group $(\mathrm{P}<0.05)$. In addition, the ratios of patients with abnormal liver function were calculated in the two groups (data not shown), and the proportion of patients with hepatic fibrosis and liver function values above the normal range was higher in the $\mathrm{HBeAg}$-positive group than that in the $\mathrm{HBeAg}$-negative group, following blood tests for ALT, AST, GGT and TBA. However, the abnormality rates of TP, ALB and GLB were much higher in the HBeAg-negative patients compared with those in $\mathrm{HBeAg}$-positive individuals. 
Table IV. Differences in liver function markers between males and females in the HBeAg-positive and -negative groups.

\begin{tabular}{|c|c|c|c|c|c|c|}
\hline \multirow[b]{2}{*}{ Parameter } & \multicolumn{3}{|c|}{ HBeAg-negative $(n=254)$} & \multicolumn{3}{|c|}{ HBeAg-positive $(n=224)$} \\
\hline & Males $(n=124)$ & Females $(n=130)$ & P-value & Males $(n=130)$ & Females $(n=94)$ & P-value \\
\hline Age (years) & $44.03 \pm 14.55$ & $44.69 \pm 15.03$ & 0.723 & $37.90 \pm 11.59$ & $36.24 \pm 14.20$ & 0.353 \\
\hline HBV DNA $\left(\log _{10} \mathrm{IU} / \mathrm{ml}\right)$ & $3.68 \pm 1.36$ & $3.32 \pm 1.04$ & 0.019 & $5.21 \pm 1.88$ & $5.97 \pm 1.85$ & 0.003 \\
\hline \multicolumn{7}{|l|}{ Liver function parameters } \\
\hline $\mathrm{TP}(\mathrm{g} / \mathrm{l})$ & $68.03 \pm 7.92$ & $68.46 \pm 7.65$ & 0.663 & $69.96 \pm 5.69$ & $70.05 \pm 6.93$ & 0.918 \\
\hline $\operatorname{ALB}(g / 1)$ & $43.33 \pm 6.37$ & $41.64 \pm 6.14$ & 0.033 & $43.15 \pm 6.55$ & $41.23 \pm 7.05$ & 0.038 \\
\hline GLB (g/l) & $24.70 \pm 4.65$ & $26.83 \pm 4.45$ & $<0.001$ & $26.81 \pm 5.41$ & $28.38 \pm 4.85$ & 0.027 \\
\hline $\mathrm{A} / \mathrm{G}$ & $1.81 \pm 0.42$ & $1.59 \pm 0.34$ & $<0.001$ & $1.69 \pm 0.44$ & $1.51 \pm 0.34$ & 0.001 \\
\hline TBIL $(\mu \mathrm{mol} / \mathrm{l})$ & $23.67 \pm 21.74$ & $25.32 \pm 59.54$ & 0.773 & $25.82 \pm 32.63$ & $28.18 \pm 55.27$ & 0.692 \\
\hline DBIL $(\mu \mathrm{mol} / \mathrm{l})$ & $7.18 \pm 11.52$ & $9.27 \pm 36.15$ & 0.540 & $8.75 \pm 17.54$ & $9.54 \pm 30.27$ & 0.809 \\
\hline IBIL $(\mu \mathrm{mol} / \mathrm{l})$ & $16.49 \pm 11.27$ & $16.05 \pm 23.95$ & 0.851 & $17.06 \pm 15.63$ & $18.64 \pm 29.64$ & 0.609 \\
\hline $\operatorname{ALT}(\mathrm{U} / \mathrm{l})$ & $73.44 \pm 131.59$ & $58.42 \pm 232.17$ & 0.530 & $120.90 \pm 326.13$ & $82.18 \pm 176.34$ & 0.297 \\
\hline AST (U/l) & $58.18 \pm 187.88$ & $53.84 \pm 165.32$ & 0.872 & $117.13 \pm 319.67$ & $85.23 \pm 204.36$ & 0.492 \\
\hline AST/ALT & $0.86 \pm 0.45$ & $1.19 \pm 0.80$ & 0.001 & $0.85 \pm 0.44$ & $1.32 \pm 1.84$ & 0.031 \\
\hline GGT (U/l) & $47.96 \pm 40.02$ & $36.58 \pm 76.45$ & 0.228 & $85.28 \pm 102.63$ & $37.51 \pm 40.46$ & $<0.001$ \\
\hline ALP (U/1) & $97.04 \pm 34.88$ & $97.51 \pm 50.58$ & 0.944 & $126.05 \pm 103.63$ & $98.16 \pm 49.33$ & 0.051 \\
\hline $\mathrm{TBA}(\mu \mathrm{mol} / \mathrm{l})$ & $10.81 \pm 25.26$ & $8.75 \pm 17.48$ & 0.534 & $24.70 \pm 57.58$ & $18.26 \pm 43.44$ & 0.467 \\
\hline \multicolumn{7}{|l|}{ Hepatic fibrosis } \\
\hline $\mathrm{HA}(\mathrm{ng} / \mathrm{ml})$ & $171.77 \pm 132.36$ & $178.71 \pm 158.17$ & 0.888 & $317.36 \pm 340.44$ & $238.56 \pm 236.65$ & 0.592 \\
\hline LN (ng/ml) & $94.83 \pm 50.48$ & $106.24 \pm 54.00$ & 0.420 & $145.18 \pm 137.02$ & $96.53 \pm 52.32$ & 0.194 \\
\hline PCIIINP (ng/ml) & $56.69 \pm 43.78$ & $59.16 \pm 64.18$ & 0.863 & $65.36 \pm 83.64$ & $61.06 \pm 69.89$ & 0.727 \\
\hline IV-C (ng/ml) & $71.98 \pm 37.00$ & $80.72 \pm 70.32$ & 0.588 & $136.27 \pm 84.50$ & $97.06 \pm 86.56$ & 0.248 \\
\hline
\end{tabular}

Values are expressed as the mean \pm standard deviation. Statistical analysis was performed using independent Student's t-test in the HBeAg-negative and -positive groups. TP, total protein; ALB, albumin; GLB, globulin; A/G, albumin/globulin; TBIL, total bilirubin; DBIL, direct bilirubin; IBIL, indirect bilirubin; ALT, alanine aminotransferase; AST, aspartate aminotransferase; GGT, $\gamma$-glutamyl transpeptidase; ALP, alkaline phosphatase; TBA, total biliary acid; HA, hyaluronic acid; LN, laminin; PCIIINP, procollagen III N-terminal peptide; IV-C, serum IV collagen; $\mathrm{HBeAg}$, hepatitis B e antigen.

Different responses to chronic $H B V$ infection in female and male patients. The sex disparity of HBV-associated liver diseases has been noted for a number of years (19). This may be due to the different effects of sex hormones (25). In order to evaluate the contribution of sex to the progression of chronic HBV infection, the patients were divided into two groups by gender in the HBeAg seronegative and seropositive groups (Table IV). There was no age difference between males and females in the seropositive and seronegative HBeAg groups $(\mathrm{P}=0.723$ in the HBeAg-negative group and $\mathrm{P}=0.353$ the $\mathrm{HBe} A g$-positive group). The male patients exhibited increased ALB and A/G levels when compared with females, regardless of their HBeAg status. By contrast, GLB and AST/ALT values were higher in females than in males $(\mathrm{GLB}, \mathrm{P}<0.001$ in the HBeAg-negative group and $\mathrm{P}=0.027$ in the $\mathrm{HBeAg}$-positive group; AST/ALT, $\mathrm{P}=0.001$ in the $\mathrm{HBeAg}$-negative group and $\mathrm{P}=0.031$ in the $\mathrm{HBeAg}$-positive group).

Among the $\mathrm{HBeAg}$-negative patients, males had higher HBV DNA copies than females $(\mathrm{t}=-2.368, \mathrm{P}=0.019)$ and a greater number of male patients had increased abnormal ratios of liver function biomarkers (TP, GLB, A/G, ALT, GGT, TBA, TBIL, DBIL and IBIL) than females (data not shown). By contrast, female patients with seropositive HBeAg had higher HBV DNA copies than males $(\mathrm{t}=3.017, \mathrm{P}=0.003)$, and a greater number of male patients had abnormal levels of GLB, A/G, ALT, AST, GGT, ALP and TBA than female patients, even if the differences were not statistically significant (data not shown). Regarding hepatic fibrosis, female patients also had higher levels of the majority of fibrosis indicators than male patients in the $\mathrm{HBeAg}$-negative group. In addition, among the $\mathrm{HBeAg}$-positive patients, males exhibited more severe liver damage than females, as indicated by the levels of hyaluronic acid (HA), laminin (LN), PCIIINP and serum IV collagen (IV-C; Table III).

Age is closely associated with the patients' response to chronic $H B V$ infection. Age has been reported to be an important factor in the progression of chronic HBV infection. The natural course of HBV infection is complex, and is highly influenced by the age at infection (26). Therefore, the present study investigated the HBV clinical virological characteristics and liver function parameters of 478 patients with chronic HBV infection from Gansu province in different age groups ( $\leq 30,31-60$ and $\geq 61$ years of age). The majority of patients were aged 31 to 60 years. Within the HBeAg-negative and -positive groups, the difference in levels of certain biomarkers, including HBV DNA, TP, ALB and A/G were significant in 
A

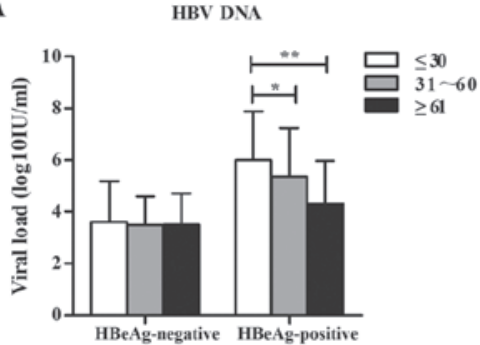

D

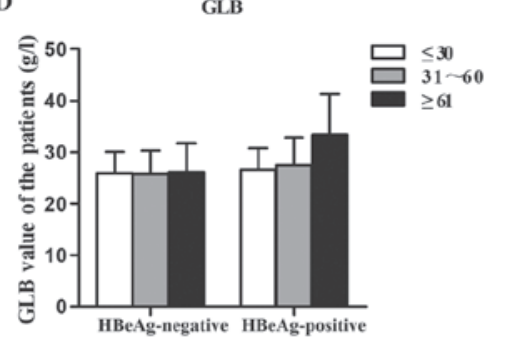

G

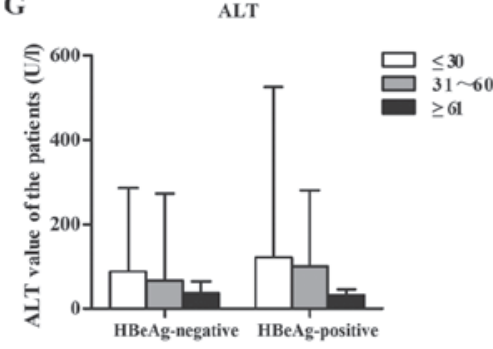

$\mathbf{J}$

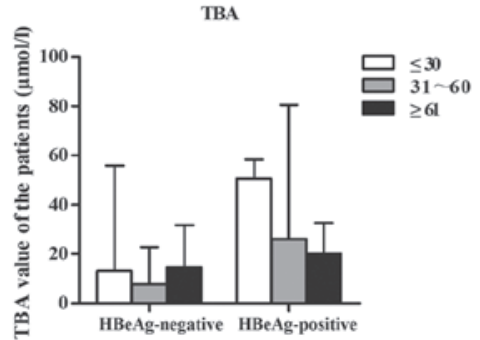

B

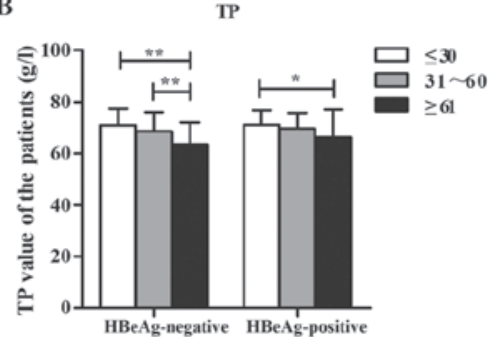

$\mathbf{E}$

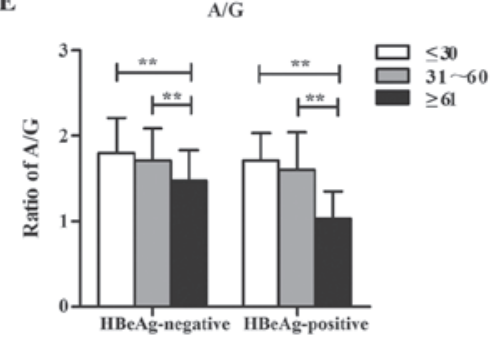

$\mathbf{H}$

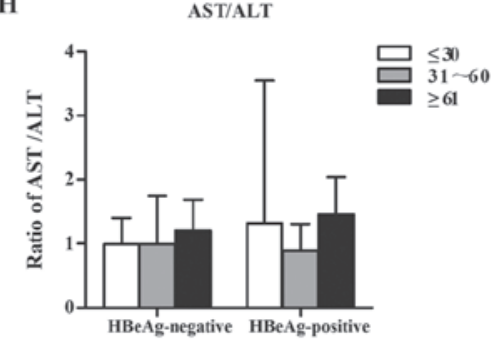

C

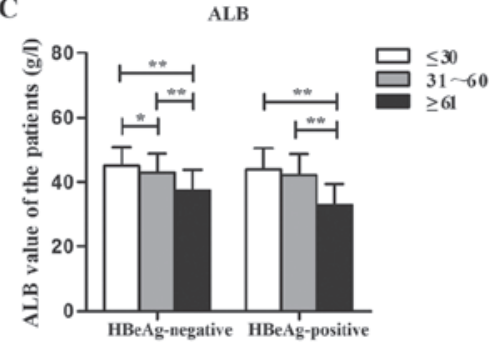

F

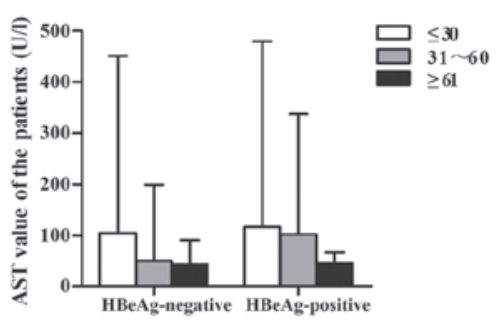

I

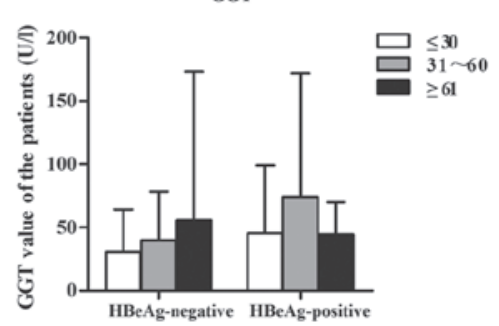

Figure 1. Patients in different age groups exhibit different reactions to HBV infection. A total of 478 patients were divided into 2 groups based on their HBeAg status (negative or positive), which were further subdivided into 3 groups according to their age ( $\leq 30,31-60$ or $\geq 61$ years). The HBeAg-negative group contained 43, 175 and 36 patients, while the HBeAg-positive group contained 75, 139 and 10 patients in the respective abovementioned age groups. The HBV clinical virological characteristics and liver function indexes were compared among the different age groups of HBeAg-positive and -negative subjects. (A) Viral load of HBV in the different groups. (B-J) Liver function biomarkers, including (B) TP, (C) ALB, (D) GLB, (E) the ratio of A/G, (F) AST, (G) ALT, (H) the ratio of AST/ALT, (I) GGT and (J) TBA. Statistical analysis between different groups was performed using one-way analysis of variance, and an independent Student's t-test was used to analyze the differences between two groups following correction via the Bonferroni method. ${ }^{*} \mathrm{P}<0.05$ and ${ }^{* *} \mathrm{P}<0.01$. HBV, hepatitis B virus; HBeAg, hepatitis B e antigen; TP, total protein; ALB, albumin; GLB, globulin; ALT, alanine aminotransferase; AST, aspartate aminotransferase; GGT, $\gamma$-glutamyl transpeptidase; TBA, total biliary acid.

patients $<30$ years old or between 31-60 years, when compared with those $\geq 61$ years. The values of the majority of biomarkers exhibited an evident decreasing trend with increasing age, although the differences were not statistically significant in certain cases, except for GLB (Fig. 1).

DNA replication levels are associated with HBeAg expression. To further identify the association of DNA replication levels with $\mathrm{HBeAg}$ expression, the patients were divided into 3 groups $\left(\leq 5.00 \times 10^{2}, 5.01 \times 10^{2}-10^{4}\right.$ and $10^{5}-1.0 \times 10^{8}$ $\mathrm{IU} / \mathrm{ml})$, according to HBV DNA levels. Low levels of viral load $\left(5.01 \times 10^{2}-10^{4} \mathrm{IU} / \mathrm{ml}\right)$ were predominantly observed in HBeAg-negative patients who had less viral replication, while patients with seropositive $\mathrm{HBeAg}$ had a higher number of viral copies $\left(10^{5}-10^{8} \mathrm{IU} / \mathrm{ml} ;\left(\chi^{2}=117.302, \mathrm{P}<0.001\right.\right.$; data not shown). Furthermore, to investigate how different levels of DNA replication affected the patients' liver function, the present study explored the liver function indexes that were closely associated with HBV DNA levels using Spearman correlation coefficient analysis (Table V). The results revealed that, in all of the patients, HBV DNA levels were positively associated with GLB, ALT, AST, GGT and TBA, and negatively associated with A/G and AST/ALT. The patients were then divided into different groups according to sex and age based on the different $\mathrm{HBeAg}$ status. The ALT and AST values increased with rising HBV DNA levels in all male and female patients with negative HBeAg status and decreased in female patients with $\mathrm{HBeAg}$ positivity. Of 
Table V. Correlation of HBV DNA and liver function parameters in all patients.

\begin{tabular}{lrr}
\hline Liver function parameter & $\mathrm{r}$ & P-value \\
\hline TP & $0.078^{\mathrm{a}}$ & 0.090 \\
ALB & $-0.080^{\mathrm{b}}$ & 0.083 \\
GLB & $0.161^{\mathrm{a}}$ & $<0.001$ \\
A/G & $-0.130^{\mathrm{b}}$ & 0.005 \\
TBIL & $0.029^{\mathrm{a}}$ & 0.534 \\
DBIL & $0.025^{\mathrm{a}}$ & 0.589 \\
IBIL & $0.036^{\mathrm{a}}$ & 0.438 \\
ALT & $0.305^{\mathrm{a}}$ & $<0.001$ \\
AST & $0.307^{\mathrm{a}}$ & $<0.001$ \\
AST/ALT & $-0.115^{\mathrm{b}}$ & 0.043 \\
GGT & $0.166^{\mathrm{a}}$ & 0.003 \\
ALP & $0.035^{\mathrm{a}}$ & 0.537 \\
TBA & $0.147^{\mathrm{a}}$ & 0.010 \\
\hline
\end{tabular}

Significance was determined using Spearman correlation coefficient analysis $(n=478) . r$ is the correlation coefficient of HBV DNA and

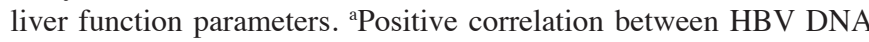
and the respective liver function parameter; ${ }^{b}$ Negative correlation between HBV DNA and the respective liver function parameter. TP, total protein; ALB, albumin; GLB, globulin; A/G, albumin/globulin; TBIL, total bilirubin; DBIL, direct bilirubin; IBIL, indirect bilirubin; ALT, alanine aminotransferase; AST, aspartate aminotransferase; GGT, $\gamma$-glutamyl transpeptidase; ALP, alkaline phosphatase; TBA, total biliary acid.

note, in the $\mathrm{HBeAg}$-negative group, numerous parameters (e.g. TBA), exhibited a positive correlation with HBV DNA levels in female patients, whereas in HBeAg-positive female patients, TBA had a negative association with HBV DNA levels, as presented in Table VI. Finally, the same analysis was also performed for different age groups in the HBeAg seronegative and -positive groups. The results revealed no marked correlation between liver function indexes and HBV DNA when the patients were aged $\geq 61$ years (Tables VII and VIII). Furthermore, in HBeAg-negative patients, the liver function parameters were affected the most by the HBV DNA replication levels in the age groups of $\leq 30$ and 31-60 years, while this result was not observed in the $\mathrm{HBeAg}$-positive patients.

\section{Discussion}

HBV infection has been a great public health concern for a number of years. It may develop into cirrhosis and $\mathrm{HCC}$ if it is not treated in a timely and effective manner. The natural course of HBV infection is complex and is highly influenced by the host and virological factors. In the present study, it was observed that HBV progression and liver damage were not only associated with $\mathrm{HBeAg}$ expression patterns and $\mathrm{HBV}$ activity, but also host characteristics, including gender and age at diagnosis.

HBeAg is a soluble protein in the core particles of HBV, which is processed from the precore protein (27). A number of studies have reported that $\mathrm{HBeAg}$ serves a critical role in chronic HBV infection treatment, prognosis and disease progression $(28,29)$. Patients with seropositive $\mathrm{HBeAg}$ have an increased risk to develop cirrhosis and HCC. Therefore, $\mathrm{HBeAg}$ has been regarded as an important indicator of disease severity; it also contributes to disease diagnosis and the formulation of treatment strategies. However, the results of the present and other studies have demonstrated that serum $\mathrm{HBeAg}$ patterns are not always positively associated with HBV DNA levels (23). To be more precise, several factors, including patients' demographic characteristics, should be considered in the treatment, prognostication and assessment of disease progression. In the present study, gender and age were critical in the diagnosis, selection of therapeutic options and determination of liver injury. Of note, the present results revealed that more male patients expressed $\mathrm{HBeAg}$, while less female patients had detectable $\mathrm{HBeAg}$ in the serum. However, females with seropositive HBeAg had higher HBV DNA copies than male patients. It is possible that an unhealthy lifestyle, including smoking (30), alcohol consumption and a nocturnal daily rhythm, which have been noted to be more common in men than in women, may have a negative effect resulting in active hepatitis and the promotion of liver disease progression. Females may present with an increased activity of HBV infection as a result of the different effects of estrogen and androgen on the host's immune response $(25,31,32)$. In addition, males and females exhibited a difference in HBV DNA levels, indicators of hepatic fibrosis and abnormal ratios of liver function parameters in the $\mathrm{HBeAg-negative} \mathrm{and} \mathrm{-positive} \mathrm{groups.} \mathrm{In}$ the $\mathrm{HBeAg}$-positive group, the differences between male and female patients were much greater regarding HBV DNA levels and liver function parameters. When considering age, the present study confirmed that HBV DNA levels decreased with advanced age, but there was no evident correlation between liver function indexes and HBV DNA in patients aged $\geq 61$ years. Certain previous studies have indicated that liver regeneration and cellular maintenance may be impaired with advanced age $(33,34)$. Furthermore, in another study, a senior population exhibited impaired endocytosis of the liver sinusoidal endothelial cells and increased leukocyte adhesion, which may reduce hepatic perfusion (35). All of these factors probably contribute to the changes in liver function in the older population. HBV replication may be restrained at the same time. Therefore, the $\mathrm{HBeAg}$ serum level should not be considered as a sole, independent indicator for disease diagnosis and treatment. It is necessary to determine more effective treatment strategies by considering a variety of factors in patients, e.g., gender and age, in addition to DNA replication levels and liver function parameters.

Hepatic fibrosis indexes, including HA, LN, PCIIINP and IV-C, are considered to have a better correlation with liver fibrosis severity when compared with other available tests (35). In the present study, all $\mathrm{HBeAg}$-positive patients had higher levels of hepatic fibrosis indexes and higher abnormal ratios of hepatic fibrosis values in their serum when compared with $\mathrm{HBe} A g-$ negative patients, particularly with regard to IV-C. However, gender had no marked effect on liver fibrosis. Thus, HBeAg may be considered as an independent and effective factor for the prognosis and early diagnosis of liver fibrosis. 
Table VI. Correlation of HBV DNA and liver function parameters in different groups.

\begin{tabular}{|c|c|c|c|c|c|c|c|c|}
\hline \multirow[b]{3}{*}{ Parameter } & \multicolumn{4}{|c|}{ HBeAg-negative } & \multicolumn{4}{|c|}{ HBeAg-positive } \\
\hline & \multicolumn{2}{|c|}{ Males $(n=124)$} & \multicolumn{2}{|c|}{ Females $(n=130)$} & \multicolumn{2}{|c|}{ Males $(n=130)$} & \multicolumn{2}{|c|}{ Females $(n=94)$} \\
\hline & $\mathrm{r}$ & P-value & $\mathrm{r}$ & P-value & $\mathrm{r}$ & P-value & $\mathrm{r}$ & P-value \\
\hline $\mathrm{TP}$ & $-0.120^{\mathrm{a}}$ & 0.187 & $0.169^{b}$ & 0.056 & $0.118^{\mathrm{b}}$ & 0.187 & $0.026^{\mathrm{b}}$ & 0.803 \\
\hline ALB & $-0.203^{\mathrm{a}}$ & 0.024 & $0.050^{\mathrm{b}}$ & 0.577 & $-0.136^{a}$ & 0.127 & $0.067^{\mathrm{b}}$ & 0.521 \\
\hline GLB & $0.050^{\mathrm{b}}$ & 0.583 & $0.210^{\mathrm{b}}$ & 0.017 & $0.153^{\mathrm{b}}$ & 0.085 & $-0.165^{a}$ & 0.111 \\
\hline $\mathrm{A} / \mathrm{G}$ & $-0.128^{\mathrm{a}}$ & 0.157 & $-0.094^{\mathrm{a}}$ & 0.292 & $-0.159^{\mathrm{a}}$ & 0.074 & $0.172^{\mathrm{b}}$ & 0.098 \\
\hline TBIL & $-0.153^{\mathrm{a}}$ & 0.092 & $0.180^{\mathrm{b}}$ & 0.041 & $-0.119^{a}$ & 0.184 & $-0.106^{\mathrm{a}}$ & 0.308 \\
\hline DBIL & $0.166^{\mathrm{b}}$ & 0.066 & $0.161^{\mathrm{b}}$ & 0.069 & $-0.127^{\mathrm{a}}$ & 0.156 & $-0.228^{\mathrm{a}}$ & 0.027 \\
\hline IBIL & $0.134^{\mathrm{b}}$ & 0.141 & $0.188^{\mathrm{b}}$ & 0.033 & $-0.088^{a}$ & 0.325 & $-0.023^{\mathrm{a}}$ & 0.826 \\
\hline ALT & $0.341^{\mathrm{b}}$ & $<0.001$ & $0.300^{\mathrm{b}}$ & 0.001 & $0.319^{b}$ & $<0.001$ & $-0.016^{\mathrm{a}}$ & 0.877 \\
\hline $\mathrm{AST}$ & $0.395^{\mathrm{b}}$ & $<0.001$ & $0.317^{\mathrm{b}}$ & 0.002 & $0.337^{\mathrm{b}}$ & 0.003 & $-0.168^{a}$ & 0.186 \\
\hline AST/ALT & $0.029^{\mathrm{b}}$ & 0.797 & $-0.149^{\mathrm{a}}$ & 0.160 & $-0.245^{\mathrm{a}}$ & 0.033 & $-0.174^{\mathrm{a}}$ & 0.168 \\
\hline GGT & $0.116^{\mathrm{b}}$ & 0.298 & $0.192^{\mathrm{b}}$ & 0.065 & $0.281^{\mathrm{b}}$ & 0.014 & $-0.309^{a}$ & 0.013 \\
\hline ALP & $0.140^{\mathrm{b}}$ & 0.210 & $0.192^{\mathrm{b}}$ & 0.069 & $-0.007^{\mathrm{a}}$ & 0.952 & $-0.403^{\mathrm{a}}$ & 0.001 \\
\hline TBA & $0.238^{\mathrm{b}}$ & 0.035 & $0.305^{\mathrm{b}}$ & 0.003 & $-0.071^{\mathrm{a}}$ & 0.546 & $-0.296^{\mathrm{a}}$ & 0.018 \\
\hline
\end{tabular}

Significance was determined using Spearman correlation coefficient analysis in each group. $r$ is the correlation coefficient of HBV DNA and liver function parameters. ${ }^{a}$ Negative correlation between HBV DNA and the respective liver function parameter; ${ }^{b}$ positive correlation between HBV DNA and the respective liver function parameter. TP, total protein; ALB, albumin; GLB, globulin; A/G, albumin/globulin; TBIL, total bilirubin; DBIL, direct bilirubin; IBIL, indirect bilirubin; ALT, alanine aminotransferase; AST, aspartate aminotransferase; GGT, $\gamma$-glutamyl transpeptidase; ALP, alkaline phosphatase; TBA, total biliary acid; HBeAg, hepatitis B e antigen.

Table VII. Correlation of HBV DNA and liver function parameters in hepatitis B e antigen-negative patients in different age groups.

\begin{tabular}{|c|c|c|c|c|c|c|}
\hline \multirow[b]{2}{*}{ Parameters } & \multicolumn{2}{|c|}{$\leq 30$ years $(n=43)$} & \multicolumn{2}{|c|}{$31-60$ years $(n=175)$} & \multicolumn{2}{|c|}{$\geq 61$ years $(n=36)$} \\
\hline & $\mathrm{r}$ & P-value & $\mathrm{r}$ & P-value & $\mathrm{r}$ & P-value \\
\hline $\mathrm{TP}$ & $-0.098^{\mathrm{a}}$ & 0.537 & $0.058^{\mathrm{b}}$ & 0.446 & $0.014^{\mathrm{b}}$ & 0.938 \\
\hline ALB & $-0.044^{\mathrm{a}}$ & 0.056 & $-0.059^{\mathrm{a}}$ & 0.435 & $-0.212^{\mathrm{a}}$ & 0.220 \\
\hline GLB & $-0.056^{\mathrm{a}}$ & 0.726 & $0.119^{b}$ & 0.116 & $0.204^{\mathrm{b}}$ & 0.240 \\
\hline $\mathrm{A} / \mathrm{G}$ & $0.091^{\mathrm{b}}$ & 0.566 & $-0.082^{\mathrm{a}}$ & 0.283 & $-0.335^{\mathrm{a}}$ & 0.049 \\
\hline TBIL & $0.280^{\mathrm{b}}$ & 0.260 & $0.159^{\mathrm{b}}$ & 0.035 & $0.107^{\mathrm{b}}$ & 0.540 \\
\hline DBIL & $0.280^{\mathrm{b}}$ & 0.072 & $0.173^{\mathrm{b}}$ & 0.022 & $0.003^{\mathrm{b}}$ & 0.988 \\
\hline IBIL & $0.260^{\mathrm{b}}$ & 0.096 & $0.154^{\mathrm{b}}$ & 0.042 & $0.154^{\mathrm{b}}$ & 0.377 \\
\hline ALT & $0.385^{\mathrm{b}}$ & 0.012 & $0.318^{\mathrm{b}}$ & $<0.001$ & $0.277^{\mathrm{b}}$ & 0.102 \\
\hline $\mathrm{AST}$ & $0.638^{\mathrm{b}}$ & 0.001 & $0.317^{\mathrm{b}}$ & 0.001 & $0.238^{\mathrm{b}}$ & 0.169 \\
\hline AST/ALT & $0.112^{\mathrm{b}}$ & 0.619 & $-0.113^{\mathrm{a}}$ & 0.232 & $-0.204^{\mathrm{a}}$ & 0.239 \\
\hline GGT & $0.213^{\mathrm{b}}$ & 0.329 & $0.188^{b}$ & 0.042 & $0.233^{\mathrm{b}}$ & 0.179 \\
\hline ALP & $0.476^{\mathrm{b}}$ & 0.022 & $0.187^{\mathrm{b}}$ & 0.045 & $0.008^{\mathrm{b}}$ & 0.962 \\
\hline TBA & $0.523^{\mathrm{b}}$ & 0.010 & $0.317^{\mathrm{b}}$ & 0.001 & $0.043^{\mathrm{b}}$ & 0.808 \\
\hline
\end{tabular}

Significance was determined using Spearman correlation coefficient analysis. $r$ is the correlation coefficient of HBV DNA and liver function parameters. ${ }^{a}$ Negative correlation between HBV DNA and the respective liver function parameter; ${ }^{b}$ positive correlation between HBV DNA and the respective liver function parameter. TP, total protein; ALB, albumin; GLB, globulin; A/G, albumin/globulin; TBIL, total bilirubin; DBIL, direct bilirubin; IBIL, indirect bilirubin; ALT, alanine aminotransferase; AST, aspartate aminotransferase; GGT, $\gamma$-glutamyl transpeptidase; ALP, alkaline phosphatase; TBA, total biliary acid.

HBeAg expression is closely associated with the activity of the virus and may be further influence liver disease progression.
For the majority of the HBeAg seropositive patients of the present study, the liver function values exhibited an increasing 
Table VIII. Correlation of HBV DNA and liver function parameters in hepatitis B e antigen-positive patients of different ages.

\begin{tabular}{|c|c|c|c|c|c|c|}
\hline \multirow[b]{2}{*}{ Parameter } & \multicolumn{2}{|c|}{$\leq 30$ years $(n=75)$} & \multicolumn{2}{|c|}{$31-60$ years $(n=139)$} & \multicolumn{2}{|c|}{$\geq 61$ years $(n=10)$} \\
\hline & $\mathrm{r}$ & P-value & $\mathrm{r}$ & P-value & $\mathrm{r}$ & P-value \\
\hline $\mathrm{TP}$ & $0.068^{a}$ & 0.569 & $-0.035^{\mathrm{b}}$ & 0.683 & $-0.153^{b}$ & 0.672 \\
\hline ALB & $-0.160^{b}$ & 0.176 & $-0.199^{b}$ & 0.019 & $-0.362^{b}$ & 0.304 \\
\hline GLB & $0.161^{\mathrm{a}}$ & 0.174 & $0.104^{\mathrm{a}}$ & 0.224 & $-0.399^{b}$ & 0.254 \\
\hline $\mathrm{A} / \mathrm{G}$ & $-0.142^{b}$ & 0.230 & $-0.166^{b}$ & 0.051 & $-0.055^{\mathrm{b}}$ & 0.880 \\
\hline TBIL & $0.062^{\mathrm{a}}$ & 0.600 & $-0.134^{\mathrm{b}}$ & 0.116 & $-0.271^{\mathrm{b}}$ & 0.449 \\
\hline DBIL & $0.020^{\mathrm{a}}$ & 0.866 & $-0.199^{b}$ & 0.019 & $-0.431^{b}$ & 0.214 \\
\hline IBIL & $0.079^{\mathrm{a}}$ & 0.505 & $-0.085^{b}$ & 0.322 & $-0.215^{b}$ & 0.551 \\
\hline ALT & $0.245^{\mathrm{a}}$ & 0.034 & $0.110^{\mathrm{a}}$ & 0.198 & $0.252^{\mathrm{a}}$ & 0.483 \\
\hline AST & $-0.017^{\mathrm{b}}$ & 0.913 & $0.207^{\mathrm{a}}$ & 0.055 & $0.239^{\mathrm{a}}$ & 0.506 \\
\hline AST/ALT & $-0.268^{b}$ & 0.082 & $-0.004^{b}$ & 0.973 & $-0.018^{b}$ & 0.960 \\
\hline GGT & $-0.214^{\mathrm{b}}$ & 0.169 & $0.070^{\mathrm{a}}$ & 0.520 & $0.632^{\mathrm{a}}$ & 0.050 \\
\hline ALP & $-0.400^{b}$ & 0.008 & $-0.166^{b}$ & 0.126 & $-0.362^{b}$ & 0.304 \\
\hline TBA & $0.041^{\mathrm{a}}$ & 0.795 & $-0.121^{b}$ & 0.268 & $-0.067^{b}$ & 0.853 \\
\hline
\end{tabular}

Significance was determined using Spearman correlation coefficient analysis. $r$ is the correlation coefficient of HBV DNA and liver function

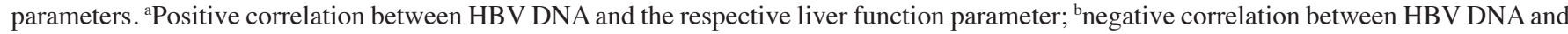
the respective liver function parameter. TP, total protein; ALB, albumin; GLB, globulin; A/G, albumin/globulin; TBIL, total bilirubin; DBIL, direct bilirubin; IBIL, indirect bilirubin; ALT, alanine aminotransferase; AST, aspartate aminotransferase; GGT, $\gamma$-glutamyl transpeptidase; ALP, alkaline phosphatase; TBA, total biliary acid.

trend, regardless of the viral replication levels. However, 87\% of HBeAg-negative patients had low-level viral replication, while the abnormal ratios of TP, ALB and GLB were higher than those in HBeAg-positive patients. This may be due to different host immune responses being activated by a varied viral load (36), and low-level viral replication not activating effective immune responses, and thereby, the virus may not be cleared in time, resulting in more severe injury of liver cells when compared with that in patients with higher replication levels of HBV DNA. In addition, the patients with lower HBV DNA levels had a higher abnormal ratio regarding PCIIINP compared with the patients with higher HBV DNA levels, which was closely associated with the activity of inflammation and the formation of liver fibrosis; the possible reasons may be associated with insufficient immune responses and the lack of effective virus elimination. A larger cohort study is underway to verify this hypothesis.

As a complicated and chronic disease, hepatitis B treatment efficacy is also affected by many additional factors, including the type of drug treatment, duration of drug treatment and the time of hepatitis B infection (37-40). In the present study, perhaps due to the limitation of patient cohort size, no differences between age, sex, duration of treatment or the time of infection were observed between patients. According to the Guidelines for the Prevention and Treatment of Chronic Hepatitis B from 2015 (24), the inpatients were treated with ETV and/or TDF, and only a small number were treated with other drugs, including LAM, FTC, LDT and ADV. Besides the different responses to viral infection, patients may respond differently to the various drugs administered, which may also affect disease progression. Although the current authors detected the gene mutations that cause resistance/sensitization to different drug treatments within a previous study with more detail, the association between drug treatment and liver function requires further investigation.

In conclusion, the present study explored the importance of host factors, including sex and age, and viral factors, including HBeAg expression pattern and HBV DNA levels, in chronic $\mathrm{HBV}$ infection and progression. All of the results provide a foundation for clinical management strategies for HBV infection, promote the future development of precise medicine and be conducive to the selection of individual treatment schemes.

\section{Acknowledgements}

Not applicable.

\section{Funding}

The present study was supported by the Human Resources and Social Security Institute as Special funding for Educated Abroad Scholar in Science and Technology Activities (grant no. 2016-176).

\section{Availability of data and materials}

The datasets used during the present study are available from the corresponding author on reasonable request.

\section{Authors' contributions}

JJ performed most of the experiments. YL and CW performed the statistical analysis. RG, HX and YJ contributed to the study design and drafting of the manuscript. YW, YL, ZW, XQ and 
ZL performed the qPCR analyses. XG critically revised the manuscript for important intellectual content.

\section{Ethics approval and consent to participate}

The present study was approved by the Ethics Review Committee of Gansu Provincial Hospital (Lanzhou, China) and written informed consent was obtained from all patients.

\section{Patient consent for publication}

All patients informed and signature for all conditions in informed consent.

\section{Competing interests}

The authors declare that they have no competing interests.

\section{References}

1. Liu J, Zhang S, Wang Q, Shen H, Zhang M, Zhang Y, Yan D and Liu M: Seroepidemiology of hepatitis B virus infection in 2 million men aged 21-49 years in rural China: A population-based, cross-sectional study. Lancet Infect Dis 16: 80-86, 2016.

2. Liang X, Bi S, Yang W, Wang L, Cui G, Cui F, Zhang Y, Liu J, Gong X, Chen Y, et al: Reprint of: Epidemiological serosurvey of Hepatitis B in China-declining HBV prevalence due to Hepatitis B vaccination. Vaccine 31 (Suppl 9): J21-J28, 2013.

3. Wang Y, Zhou H, Zhang L, Zhong Q, Wang Q, Shen H, Zhang M, Huang Y, Wang A, Nelson K, et al: Prevalence of chronic hepatitis $\mathrm{B}$ and status of HBV care among rural women who planned to conceive in China. Sci Rep 7: 12090, 2017.

4. Trépo C, Chan HL and Lok A: Hepatitis B virus infection. Lancet 384: 2053-2063, 2014.

5. Lu F, Li T, Liu S and Zhuang H: Epidemiology and prevention of hepatitis B virus infection in China. J Viral Hepat 17 (Suppl 1): S4-S9, 2010.

6. Biswas A, Panigrahi R, Pal M, Chakraborty S, Bhattacharya P, Chakrabarti $S$ and Chakravarty R: Shift in the hepatitis B virus genotype distribution in the last decade among the HBV carriers from eastern India: Possible effects on the disease status and HBV epidemiology. J Med Virol 85: 1340-1347, 2013.

7. Moura IF, Lopes EP, Alvarado-Mora MV, Pinho JR and Carrilho FJ: Phylogenetic analysis and subgenotypic distribution of the hepatitis B virus in Recife, Brazil. Infect Genet Evol 14: 195-199, 2013.

8. Wang SH, Chen PJ and Yeh SH: Gender disparity in chronic hepatitis B: Mechanisms of sex hormones. J Gastroenterol Hepatol 30: 1237-1245, 2015.

9. Zheng B, Zhu Y, Wang H and Chen L: Gender disparity in hepatocellular carcinoma (HCC): Multiple underlying mechanisms. Sci China Life Sci 60: 575-584, 2017.

10. Tan Y, Ye Y, Zhou X, Chen L and Wen D: Age as a predictor of significant fibrosis features in $\mathrm{HBeAg}$-negative chronic hepatitis $B$ virus infection with persistently normal alanine aminotransferase. PLoS One 10: e0123452, 2015.

11. Zhang H, Huo M, Chao J and Liu P: Application of bayesian approach to cost-effectiveness analysis of antiviral treatments in chronic Hepatitis B. PLoS One 11: e0161936, 2016.

12. Everson GT, Shiffman ML, Hoefs JC, Morgan TR, Sterling RK, Wagner DA, Lauriski S, Curto TM, Stoddard A and Wright EC; HALT-C Trial Group: Quantitative liver function tests improve the prediction of clinical outcomes in chronic hepatitis C: Results from the Hepatitis $\mathrm{C}$ antiviral long-term treatment against cirrhosis trial. Hepatology 55: 1019-1029, 2012.

13. Ghany MG, Lok AS, Everhart JE, Everson GT, Lee WM, Curto TM, Wright EC, Stoddard AM, Sterling RK, Di Bisceglie AM, et al: Predicting clinical and histologic outcomes based on standard laboratory tests in advanced chronic hepatitis C. Gastroenterology 138: 136-146, 2010.
14. Qi Y, Gao Z, Xu G, Peng B, Liu C, Yan H, Yao Q, Sun G, Liu Y, Tang D, et al: DNA polymerase kappa is a key cellular factor for the formation of covalently closed circular DNA of Hepatitis B virus. PLoS Pathog 12: e1005893, 2016.

15. Zhang Z, Li A and Xiao X: Risk factors for intrauterine infection with hepatitis B virus. Int J Gynaecol Obstet 125: 158-161, 2014.

16. Chan H, Tse C, Mo F, Koh J, Wong VW, Wong GL, Lam Chan S, Yeo W, Sung JJ and Mok TS: High viral load and hepatitis B virus subgenotype ce are associated with increased risk of hepatocellular carcinoma. J Clin Oncol 26: 177-182, 2008.

17. Mommeja-Marin H, Mondou E, Blum M and Rousseau F: Serum HBV DNA as a marker of efficacy during therapy for chronic HBV infection: Analysis and review of the literature. Hepatology 37: 1309-1319, 2003.

18. Sanai FM, Helmy A, Bzeizi KI, Babatin MA, Al-Qahtani A, Al-Ashgar HA, Al-Mdani AS, Al-Akwaa A, Almutharea S, Khan MQ, et al: Discriminant value of serum HBV DNA levels as predictors of liver fibrosis in chronic hepatitis B. J Viral Hepat 18: e217-e225, 2011.

19. Yuen MF, Tanaka Y, Fong DY, Fung J, Wong DK, Yuen JC, But DY, Chan AO, Wong BC, Mizokami M and Lai CL: Independent risk factors and predictive score for the development of hepatocellular carcinoma in chronic hepatitis B. J Hepatol 50: 80-88, 2009.

20. Ozaki K, Matsui O, Gabata T, Kobayashi S, Koda W and Minami T: Confluent hepatic fibrosis in liver cirrhosis: Possible relation with middle hepatic venous drainage. Jpn J Radiol 31: 530-537, 2013.

21. Shirvani-Dastgerdi E, Winer BY, Celià-Terrassa T, Kang Y, Tabernero D, Yagmur E, Rodríguez-Frías F, Gregori J, Luedde T, Trautwein C, et al: Selection of the highly replicative and partially multidrug resistant rtS78T HBV polymerase mutation during TDF-ETV combination therapy. J Hepatol 67: 246-254, 2017.

22. Xiang Y, Chen P, Xia JR and Zhang LP: A large-scale analysis study on the clinical and viral characteristics of hepatitis B infection with concurrence of hepatitis B surface or E antigens and their corresponding antibodies. Genet Mol Res 16, 2017.

23. Chen P, Xie Q, Lu X, Yu C, Xu K, Ruan B, Cao H, Gao H and Li L: Serum HBeAg and HBV DNA levels are not always proportional and only high levels of $\mathrm{HBeAg}$ most likely correlate with high levels of HBV DNA: A community-based study. Medicine (Baltimore) 96: e7766, 2017.

24. Chinese Society of Hepatology of Chinese Medical Association: The Guidelines for the Prevention and Treatment of Chronic Hepatitis B (2015). Chinese Journal of experimental and Clinical Infectious Diseases (Electronic Edition) 19: 1-18, 2015.

25. Wang SH, Chen PJ and Yeh SH: Gender disparity in chronic hepatitis B: Mechanisms of sex hormones. J Gastroenterol Hepatol 30: 1237-1245, 2015.

26. Wu DL, Xu GH, Lu SM, Ma BL, Miao NZ, Liu XB, Feng JH, Liu N, Zeng QL, Hou WK, et al: Age versus clinical virological characteristics in chronic hepatitis B virus infection: A case series study in China. Eur J Gastroenterol Hepatol 24: 406-413, 2012.

27. Dong J, Ying J, Qiu X, Lu Y and Zhang M: Advanced strategies for eliminating the cccDNA of HBV. Dig Dis Sci 63: 7-15, 2018.

28. Samal J, Kandpal M and Vivekanandan P: HBeAg-induced miR-106b promotes cell growth by targeting the retinoblastoma gene. Sci Rep 7: 14371, 2017.

29. Yu Y, Wan P, Cao Y, Zhang W, Chen J, Tan L, Wang Y, Sun Z, Zhang Q, Wan Y, et al: Hepatitis B virus e antigen activates the suppressor of cytokine signaling 2 to repress interferon action. Sci Rep 7: 1729, 2017.

30. Wan DW, Tzimas D, Smith JA, Kim S, Araujo J, David R, Lobach I and Sarpel U: Risk factors for early-onset and late-onset hepatocellular carcinoma in Asian immigrants with hepatitis B in the United States. Am J Gastroenterol 106: 1994-2000, 2011.

31. Lee SA, Kim H, Won YS, Seok SH, Na Y, Shin HB, Inn KS and Kim BJ: Male-specific hepatitis B virus large surface protein variant W4P potentiates tumorigenicity and induces gender disparity. Mol Cancer 14: 23, 2015.

32. Wong VW and Janssen HL: Can we use HCC risk scores to individualize surveillance in chronic hepatitis B infection? J Hepatol 63: 722-732, 2015.

33. Furrer K, Rickenbacher A, Tian Y, Jochum W, Bittermann AG, Käch A, Humar B, Graf R, Moritz W and Clavien PA: Serotonin reverts age-related capillarization and failure of regeneration in the liver through a VEGF-dependent pathway. Proc Natl Acad Sci USA 108: 2945-2950, 2011. 
34. Zhang C and Cuervo AM: Restoration of chaperone-mediated autophagy in aging liver improves cellular maintenance and hepatic function. Nat Med 14: 959-965, 2008.

35. LE Couteur D, Cogger V, McCuskey R, DE Cabo R, Smedsrød B, Sorensen KK, Warren A and Fraser R: Age-related changes in the liver sinusoidal endothelium: A mechanism for dyslipidemia. Ann NY Acad Sci 1114: 79-87, 2007.

36. Dusséaux M, Masse-Ranson G, Darche S, Ahodantin J, Li Y, Fiquet $\mathrm{O}$, Beaumont E, Moreau P, Rivière L, Neuveut C, et al: Viral load affects the immune response to HBV in mice with humanized immune system and liver. Gastroenterology 153: 1647-1661.e9, 2017.

37. Choi JW, Kim SH, Seo JH, Cho YS, Won SY, Park BK, Jeon HH Lee YK and Lee CK: Real world experience of telbivudine versus entecavir in patients with chronic Hepatitis B, including long-term outcomes after treatment modification. Yonsei Med J 59: 383-388, 2018.
38. Wang ML, Chen EQ, Tao CM, Zhou TY, Liao J, Zhang DM, Wang $J$ and Tang H: Pronounced decline of serum HBsAg in chronic hepatitis B patients with long-term effective nucleos $(\mathrm{t})$ ide analogs therapy. Scand J Gastroenterol 52: 1420-1426, 2017.

39. Kang SH, Yim HJ, Kim HR, Kang K, Suh SJ, Lee HJ, Yoon EL, Kim JH, Seo YS, Yeon JE and Byun KS: Comparison of lamivudine plus adefovir therapy versus entecavir with or without adefovir therapy for adefovir-resistant chronic hepatitis B. J Clin Gastroenterol 48: 889-895, 2014.

40. Marcellin P, Zoulim F, Hézode C, Causse X, Roche B Truchi R, Pauwels A, Ouzan D, Dumortier J, Pageaux GP, et al: Effectiveness and safety of tenofovir disoproxil fumarate in chronic Hepatitis B: A 3-year, prospective, real-world study in france. Dig Dis Sci 61: 3072-3083, 2016. 